\title{
Growth and esterase activity of Fusarium culmorum grown in di(2- ethyl hexyl) phthalate in liquid fermentation
}

\section{Crecimiento y actividad de esterasas de Fusarium culmorum crecido en di(2-etil hexil) ftalato en fermentación liquida}

Naomi Surellem Ríos-González² ${ }^{2}$ Ángel González-Márquez ${ }^{3}$, Carmen Sánchez ${ }^{*}$

${ }^{1}$ Laboratory of Biotechnology, Research Centre of Biological Sciences, Universidad Autónoma de Tlaxcala, Ixtacuixtla, Tlaxcala C.P. 90062, Mexico.

2Ingeniería en Biotecnología, Universidad Politécnica del Valle de Toluca, Toluca, Mexico State, Mexico.

${ }^{3}$ Doctorado en Biotecnología, Universidad Autónoma Metropolitana-Iztapalapa, Mexico City, Mexico.

${ }^{*}$ Corresponding author

E-mail address: carmen.sanchezh@uatx.mx (C. Sánchez)

Article history:

Received: 8 November 2018 / Received in revised form: 16 January 2019 / Accepted: 19 January 2019 / Published online: 20 January 2019.

https://doi.org/10.29267/mxib.2019.4.1.51

\section{ABSTRACT}

Di (2-ethyl hexyl) phthalate (DEHP) is a plasticizer present in various products, mainly those made with PVC. This phthalate has attracted attention due to its important participation in the contamination of the environment. It has been reported as an endocrine-disrupting compound in mammals. Fusarium culmorum is a phytopathogenic fungus able to degrade DEHP, because it produces esterases, which are enzymes capable to break down ester bonds present in the structure of phthalates. In this research, growth, protein content and esterases activity by biochemical tests and polyacrylamide gel electrophoresis were characterized for $F$. culmorum grown in DEHP-supplemented (100 and $1500 \mathrm{mg} / \mathrm{L}$ ) media as the only carbon source in liquid fermentation. F. culmorum showed higher biomass production and esterase activity in medium supplemented with $1500 \mathrm{mg}$ of 
DEHP/L. Zymography revealed that bands with esterase activity were observed after $24 \mathrm{~h}$ and $48 \mathrm{~h}$ in media supplemented with 1500 and $100 \mathrm{mg}$ of DEHP/L, respectively. It was shown that DEHP is an inducer of esterases and that this compound was used as carbon and energy sources by $F$. culmorum. This fungus can secrete specific esterase to breakdown high concentrations of DEHP, being a promising organism for bioremediation of DEHP-polluted environments in both aquatic and terrestrial ecosystems.

Keywords: di(2-ethyl hexyl) phthalate, esterase, Fusarium culmorum, liquid fermentation.

\section{RESUMEN}

El di (2-etil hexil) ftalato (DEHP) es un plastificante presente en varios productos, principalmente en los fabricados con PVC. Este ftalato ha llamado la atención debido a su importante participación en la contaminación del medio ambiente. Se ha reportado como un compuesto que altera el sistema endocrino en los mamíferos. Fusarium culmorum es un hongo fitopatógeno capaz de degradar el DEHP, ya que produce esterasas, que son enzimas capaces de descomponer los enlaces éster presentes en la estructura de los ftalatos. En esta investigación, el crecimiento y el contenido de proteína fueron evaluadas en F. culmorum. La actividad de esterasa en este hongo también fue determinada empleando pruebas bioquímicas y electroforesis en gel de poliacrilamida. Los estudios antes mencionados fueron realizados en medios suplementados con DEHP (100 y 1500 $\mathrm{mg} / \mathrm{L}$ ) como la única fuente de carbono en fermentación líquida. F. culmorum mostró una mayor producción de biomasa y actividad de esterasa en medio suplementado con $1500 \mathrm{mg}$ de DEHP/L. La zimografía mostró bandas con actividad esterasa después de 24 horas y 48 horas en medios adicionados con 1500 y $100 \mathrm{mg}$ de DEHP/L, respectivamente. Se demostró que el DEHP es un inductor de esterasas y que este compuesto fue utilizado como fuente de carbono y energía por $F$. culmorum. Este hongo puede producir esterasa para degradar altas concentraciones de DEHP, siendo un organismo prometedor para la biorremediación de ambientes contaminados con este ftalato en ecosistemas acuáticos y terrestres.

Palabras clave: di(2-etil hexil) ftalato, esterasa, Fermentación líquida, Fusarium culmorum.

\section{INTRODUCTION}

Di (2-ethylhexyl) phthalate (DEHP) is an additive used to make plastic more flexible. It is widely used as a plasticizer for polyvinyl chloride (PVC) products, which has applications such as building materials, food packaging, cosmetics and medical devices (Peropadre et al., 2015). DEHP is an environmental pollutant. 
DEHP can be found in the environment as a result of the slow release of phthalates of plastics and other materials containing phthalates due to the weather. Accumulation in natural water causes its wide distribution within aqueous systems such as rivers, lakes and groundwater, as well as in the ecological environment. Phthalates do not bind chemically to polymer matrices and can easily disperse into the environment during production and use, and after removal (Daiem et al., 2012).

Exposure to chemicals such as phthalates can occur through a variety of sources, such as food, air, dust, and use of personal care products, phthalates end up in the human body through ingestion, inhalation or dermal absorption. Particularly, DEHP is considerate an endocrine-disrupting compound in mammals (Wittassek et al., 2010).

Different microorganisms have been used to study due to their capacity to produce enzymes able to degrade degrading phthalates. It has been reported that some species of bacteria (Zhao et al., 2016; Yang et al., 2018) and different species of fungi (Pradeep \& Benjamin, 2012; Aguilar-Alvarado et al., 2015; Ahuactzin-Pérez et al., 2018) have been able to degrade these compounds. Filamentous fungi, such as Fusarium have been widely studied (Kim et al., 2003). Fusarium culmorum is a phytopathogenic fungus able to produce esterases in the presence of high concentrations of DEHP (Ahuactzin-Pérez et al., 2016). In this research, growth, esterase activity, and molecular weight of esterase of Fusarium culmorum were evaluated in media added with DEHP (100 and $1500 \mathrm{mg} / \mathrm{L}$ ) in liquid fermentation.

\section{MATERIALS Y METHODS}

\subsection{Microorganism}

The strain of Fusarium Culmorum used belongs to the culture collection of the Research Centre for Biological Sciences (CICB) at Universidad Autónoma de Tlaxcala. This strain was isolated from the mixture of waste from a paper recycling industry, where DEHP is used as an adhesive in paper envelopes and paper emulsifiers (Aguilar-Alvarado et al., 2015). This strain grew in malt extract agar at $25^{\circ} \mathrm{C}$ and was preserved at $4{ }^{\circ} \mathrm{C}$.

\subsection{Culture media}

Two culture media were prepared containing DEHP (100 and $1500 \mathrm{mg} / \mathrm{L}$ ) and a mineral medium. The composition of the mineral medium was as follows (in $\mathrm{g} / \mathrm{L}$ ): DEHP (Sigma; purity grade 99\%), 1.0; $\mathrm{NaNO}_{3}, 3.0 ; \mathrm{K}_{2} \mathrm{HPO}_{4}, 1.0 ; \mathrm{MgSO}_{4} .7 \mathrm{H}_{2} \mathrm{O}$, $0.5 ; \mathrm{KCl}, 0.5$; and $\mathrm{FeSO}_{4} .7 \mathrm{H}_{2} \mathrm{O}, 0.01 .100 \mu \mathrm{L}$ of Tween $80 / \mathrm{L}$ were also added to the culture medium. DEHP (boiling point $385^{\circ} \mathrm{C}$ ) was added to the medium before 
autoclaving. The final $\mathrm{pH}$ was adjusted after autoclaving to 6.5 using either $0.1 \mathrm{M}$ $\mathrm{HCl}$ or $0.1 \mathrm{M} \mathrm{NaOH}$. In each flask, $50 \mathrm{ml}$ of culture medium were placed and sterilized at $120^{\circ} \mathrm{C}$ for 25 minutes, cooled and then inoculated with approximately $10^{7}$ spores. The cultures were incubated at $25^{\circ} \mathrm{C}$ for 7 days in a rotary incubator at $120 \mathrm{rpm}$.

\subsection{Biomass production and $\mathrm{pH}$ measurement}

Biomass and supernatant were separated by filtration of the culrures, and the biomass was determined by difference in dry weight between the filter paper and the biomass. The $\mathrm{pH}$ of the supernatant was measured using a digital potentiometer. The samples were taken each 112 hours during 7 days and the studies were performed in triplicate.

\subsection{Protein production}

Protein production was quantified in the supernatant of the samples using the method of Bradford (1976). In a test tube, $700 \mu \mathrm{L}$ of distilled water, $200 \mu \mathrm{L}$ of Bradford reagent and $100 \mu \mathrm{L}$ of the supernatant were added. The total protein was evaluated using a spectrophotometer at $595 \mathrm{~nm}$; the tests were done in triplicate.

\subsection{Enzymatic activity}

Specific esterase activity was evaluated in the supernatant. A substrate was used, containing; $1.108 \mathrm{~mL}$ of acetonitrile, $19.5 \mu \mathrm{L}$ of $\mathrm{p}$-nitrophenyl butyrate (PNPB), $11,08 \mathrm{~mL}$ distilled water, $4.44 \mu \mathrm{L}$ Triton $\mathrm{X}-100$ and was diluted with phosphate buffer (PH 7.5) in order to obtain $100 \mathrm{~mL}$ of substrate. A test tube containing 900

$\mu \mathrm{L}$ of substrate and $100 \mu \mathrm{L}$ of the supernatant was used. The enzymatic activity was evaluated using a spectrophotometer at $405 \mathrm{~nm}$. The studies were performed in triplicate.

\subsection{Zymographic}

Electrophoresis was carried out at 120 volts for 4 hours, using an $18 \%$ separation polyacrylamide gel and a $4 \%$ packing gel. ProteinTM Dual Precision Xtra Plus Standards was used as a molecular marker. The gels were incubated for $3 \mathrm{~h}$ in a solution containing $3 \mathrm{mM}$ of $\alpha$-naphthyl acetate, $1 \mathrm{mM}$ of fast red and phosphate buffer $100 \mathrm{mM}(\mathrm{pH}$ 7.5). Esterase activity was detected as bands marked in the gels of a reddish color. 


\section{RESULTS}

\subsection{Biomass production}

Biomass production by Fusarium Culmorum is shown in Fig. 1. The highest biomass production was obtained in the media supplemented with $1500 \mathrm{mg}$ DEHP/L. The highest biomass production was observed at $168 \mathrm{~h}$ in both media.

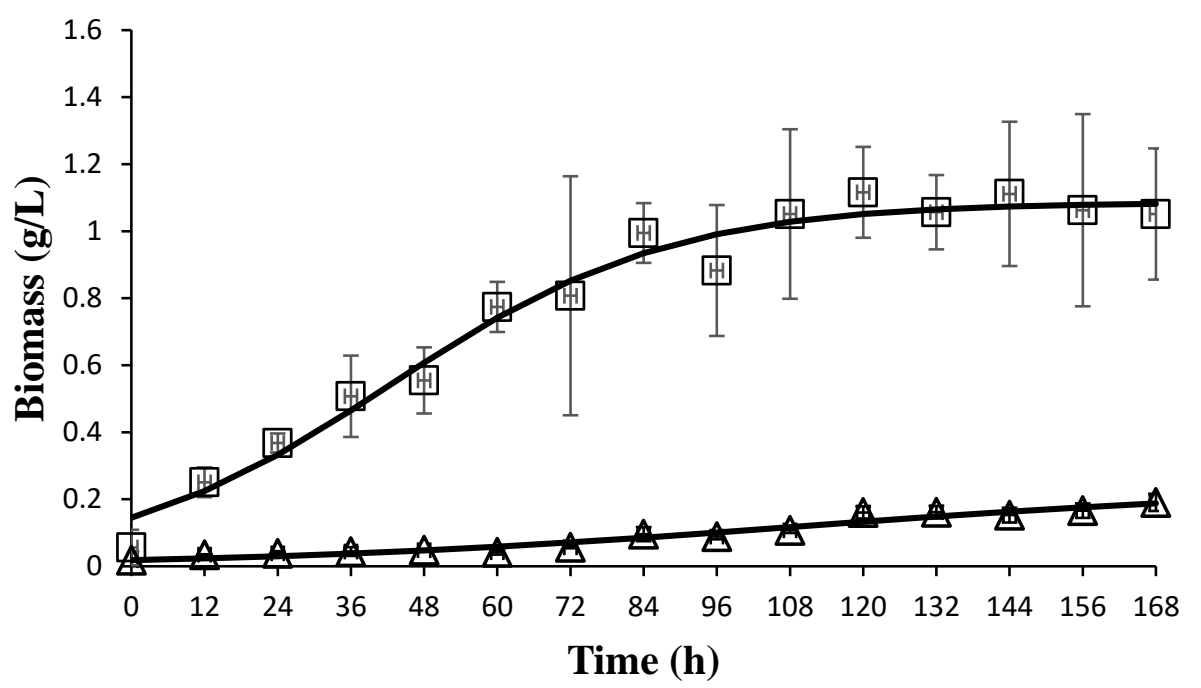

Fig. 1. Biomass production by Fusarium culmorum grown on media supplemented with $100(\Delta)$ and $1500(\square) \mathrm{mg}$ of $\mathrm{DEHP} / \mathrm{L}$ in liquid fermentation.

\subsection{Protein production}

Fig. 2 shows the protein content of Fusarium culmorum. Ian increased in protein content was observed in the media supplemented with $1500 \mathrm{mg} \mathrm{DEHP/L}$ after 72 $\mathrm{h}$, with a maximum of $0.00126 \mathrm{mg} / \mathrm{mL}$ after $48 \mathrm{~h}$. Higher protein content was observed after $84 \mathrm{~h}$ in that media supplemented with $100 \mathrm{mg}$ of DEHP/L, showing a maximum of $0.001 \mathrm{mg} / \mathrm{mL}$ after $108 \mathrm{~h}$. 


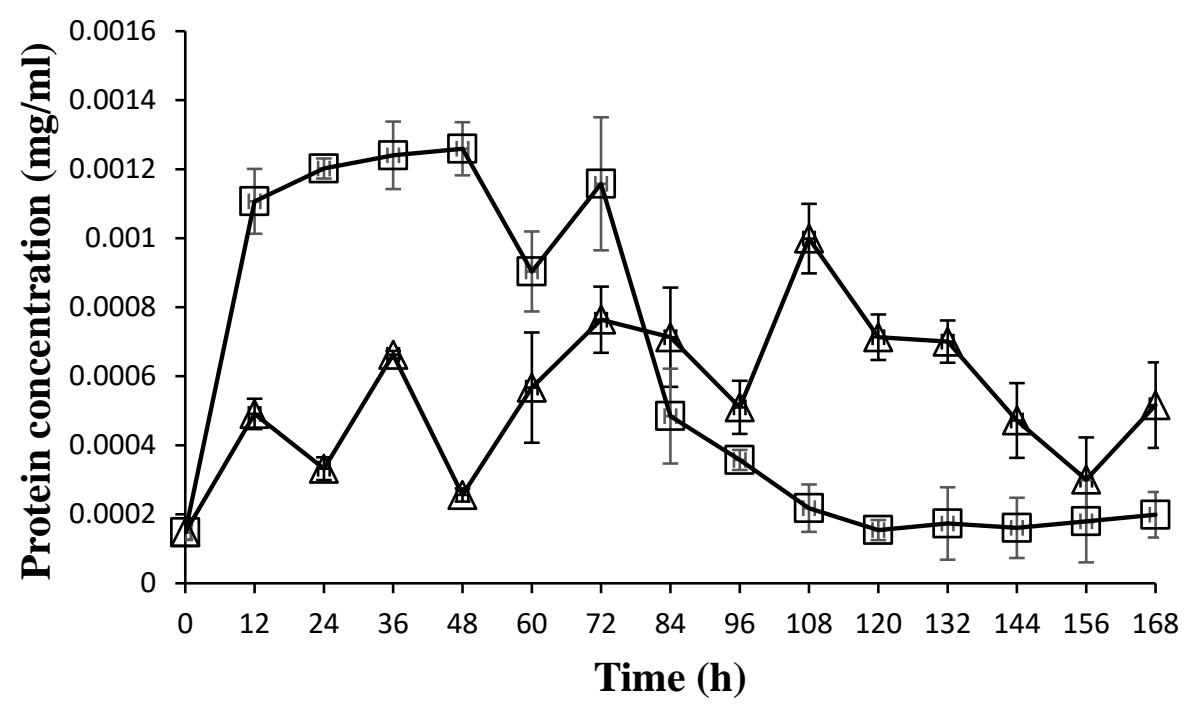

Fig. 2. Protein production by Fusarium culmorum grown in media supplemented with $100(\Delta)$ and $1500(\square) \mathrm{mg}$ of DEHP/L in liquid fermentation.

\subsection{Esterase activity and zymography}

Esterase activity was very similar in both media after $96 \mathrm{~h}$ of incubation (Fig. 3). An increase in esterase activity was observed in the media supplemented with $100 \mathrm{mg}$ DEHP/L after $108 \mathrm{~h}$. Enzymatic activity was also observed in the zymograms. In both zymograms (Fig. 4 and 5) no bands were observed during the first 48h. Intensity of the bands was similar in both zymograms after $60 \mathrm{~h}$. A slight increase in the intensity of the bands was observed after $108 \mathrm{~h}$ in the zymogram of $100 \mathrm{mg}$ of DEHP/L after $108 \mathrm{~h}$. Esterases showed an approximate molecular weight of 16 , 18, 20, 23, 25, 50, 70, 75, $150 \mathrm{kDa}$. 


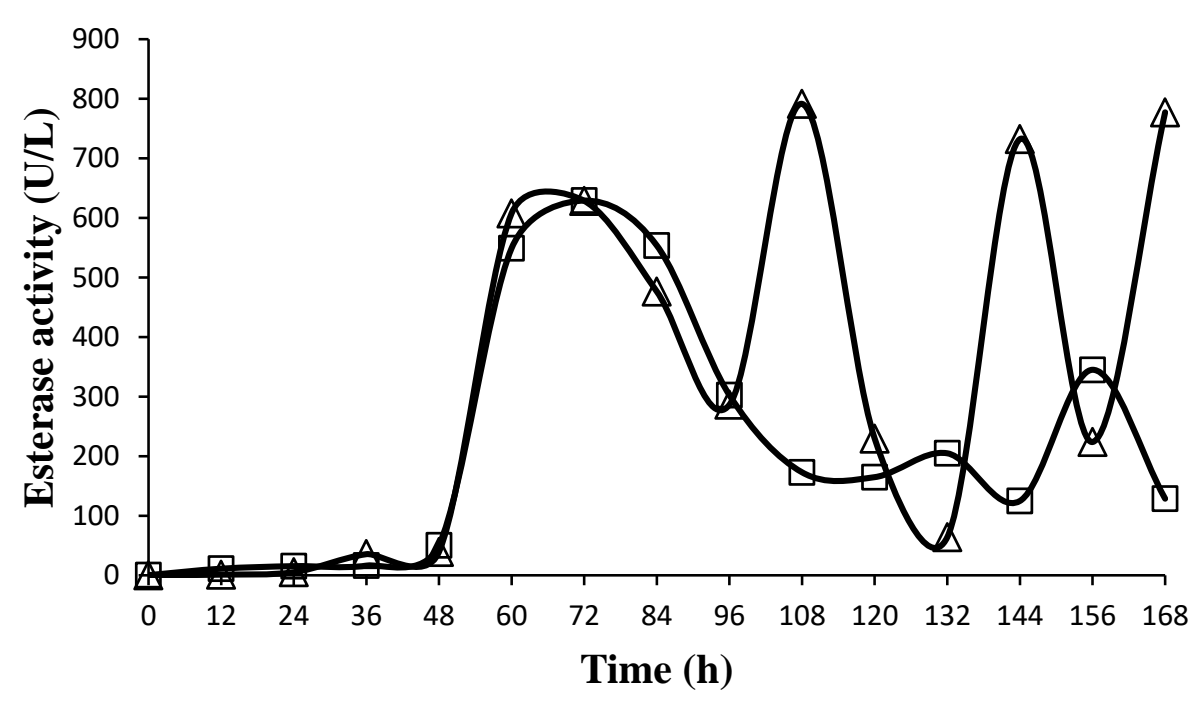

Fig. 3. Esterase activity of Fusarium culmorum grown on media supplemented with $100(\Delta)$ and $1500(\square) \mathrm{mg}$ of DEHP/L in liquid fermentation.

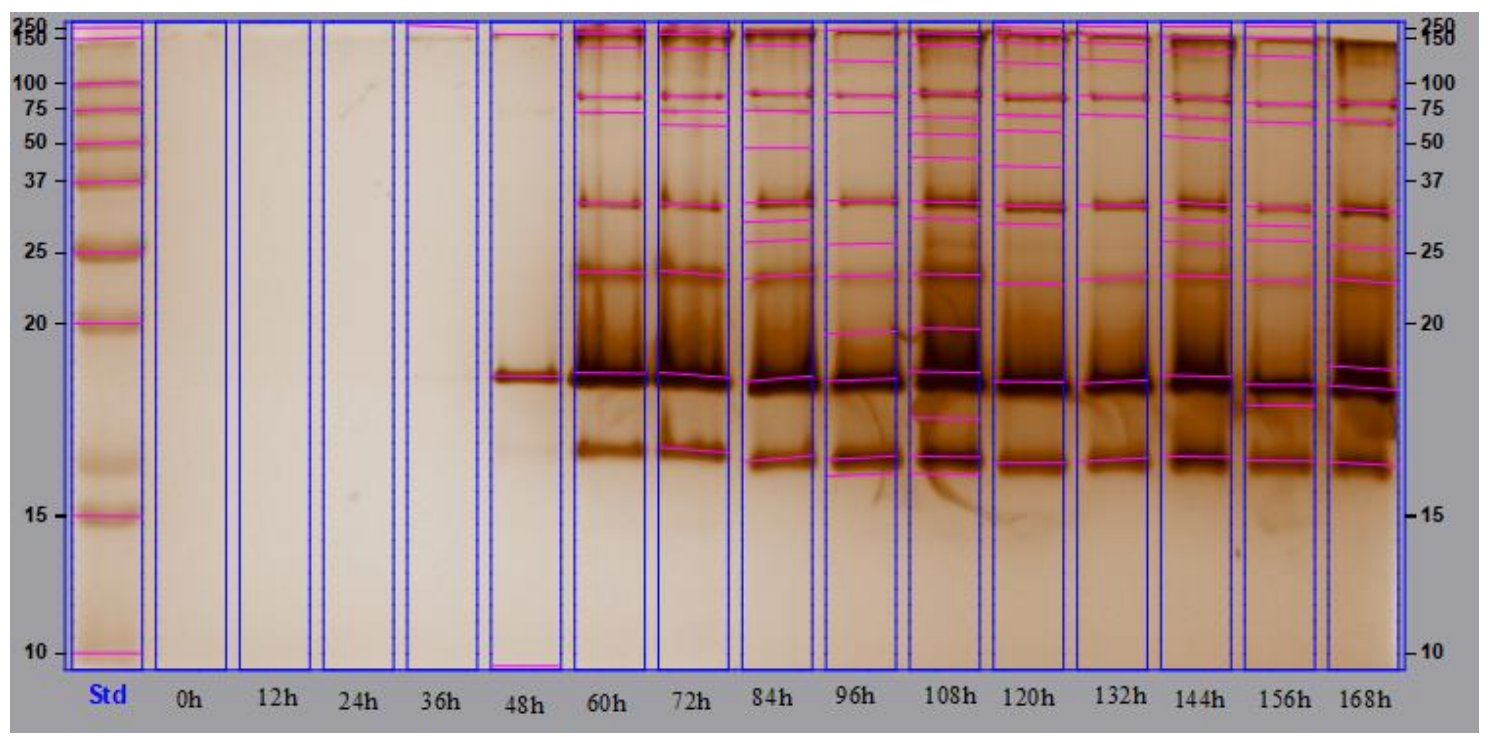

Fig. 4. Zymogram of Fusarium culmorum grown in media supplemented with 100 $\mathrm{mg}$ of $\mathrm{DEHP} / \mathrm{L}$ in liquid fermentation. 


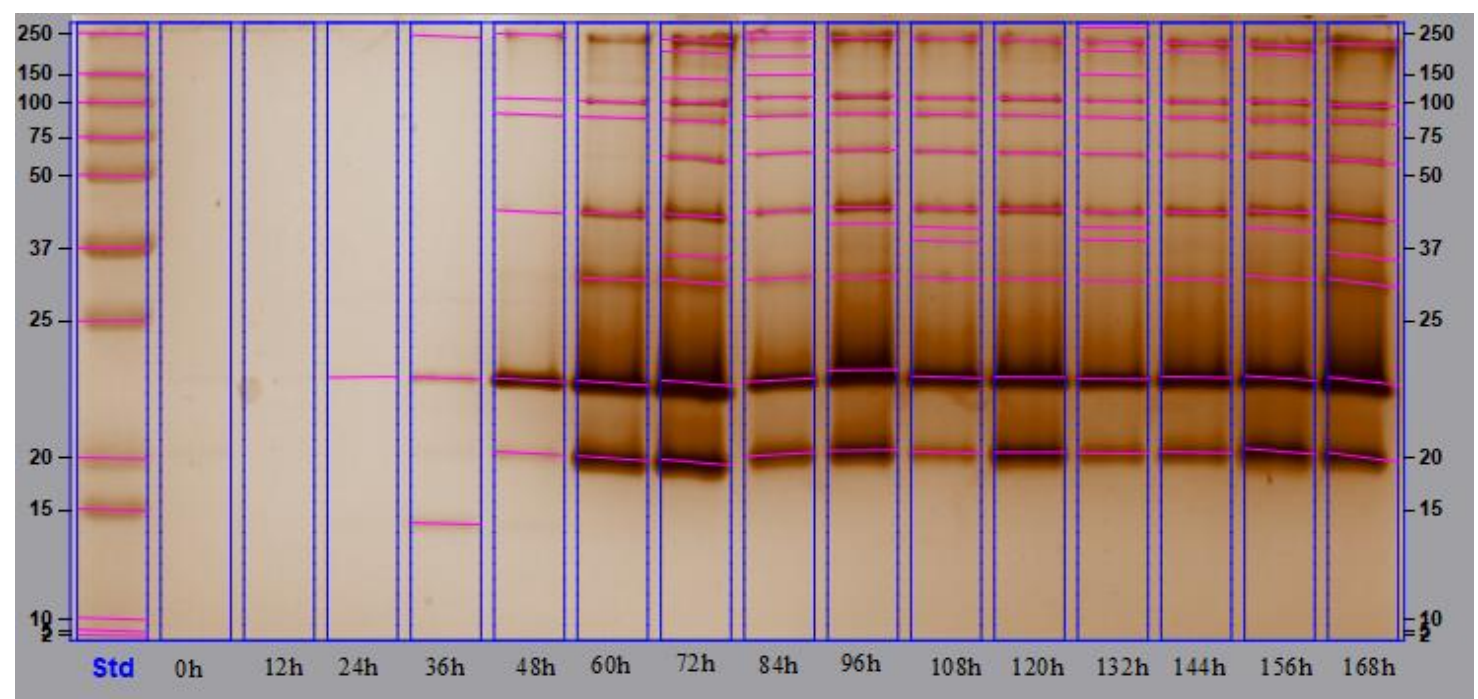

Fig. 5. Zymogram of Fusarium culmorum grown in media supplemented with 1500 $\mathrm{mg}$ of DEHP/L.

\section{DISCUSSION}

In the present work, two media were tested with different concentrations of DEHP (100 and $1500 \mathrm{mg} / \mathrm{L}$ ). F. culmorum showed a higher biomass production in the medium supplemented with $1500 \mathrm{mg}$ of DEHP/L. Aguilar-Alvarado et al. (2015) also reported that the greatest biomass production by F. culmorum was observed in the media supplemented with $1500 \mathrm{mg}$ DEHP/L. Ahuatzin-Pérez et al. (2016) reported that $F$. culmorum had the maximum biomass production media supplemented with $1000 \mathrm{mg}$ of DEHP/L, showing that this fungus used DEHP as a carbon source. In the present research, no stationary phase is observed in that medium added with 100 of DEHP/L, however, the stationary phase is observed after approx. $96 \mathrm{~h}$ in the medium supplemented with $1500 \mathrm{mg}$ of DEHP/L. Cordoba-Sosa et al. (2014) studied DEHP biodegradation (750, 1200 and $1500 \mathrm{mg}$ of $\mathrm{DEHP} / \mathrm{L})$ by $P$. ostreatus and found that the highest esterase activity was observed in the highest DEHP concentration tested $(1500 \mathrm{mg} / \mathrm{L})$. The maximum value of esterase activity in the media supplemented with $1500 \mathrm{mg}$ DEHP/L was $629.95 \mathrm{U} / \mathrm{L}$, being higher than that showed in previous studies (Ferrer-Parra et al., 2018). Ferrer-Parra et al. (2018) reported that F. culmorum had a esterase activity of $242 \mathrm{U} / \mathrm{L}$ and $350 \mathrm{U} / \mathrm{L}$ in media supplemented with $1500 \mathrm{mg}$ and $2000 \mathrm{mg}$ of $\mathrm{DEHP} / \mathrm{L}$, respectively. In the present research, the molecular weight of the bands of esterase were observed in similar range (approximately 16 to $150 \mathrm{kDa}$ ) to those reported by Ferrer-Parra et al. (2018). These studies showed that DEHP is an inducer of esterases and that this compound is used as carbon and energy sources by F. culmorum. This fungus can secrete specific esterase to breakdown 
high concentrations of DEHP, being a promising organism for bioremediation of DEHP-polluted environments in both aquatic and terrestrial ecosystems.

\section{ACKNOWLEDGMENTS}

We are grateful to Programa Delfín (a summer vacation scheme), Universidad Politécnica del Valle de Toluca and COMECyT for financial support to NSRG.

\section{CONFLICT OF INTEREST}

The authors declare that they have no conflict of interest.

\section{REFERENCES}

Aguilar-Alvarado Y., Báez-Sámchez M., Martínez-Carrera D., Ahuactzin-Pérez M., Cuamatzi-Muñoz M. \& Sánchez C. 2015. Mycelial growth and enzymatic activities of fungi isolated from recycled paper wastes grown on di(2-ethylhexyl) phthalate. Polish Journal of Environmental Studies. 24(5): 1897-1902.

Ahuactzin-Pérez M., Tlecuitl-Beristain S., García-Dávila J., González-Pérez M., Gutiérrez-Ruíz M. \& Sánchez C. 2016. Degradation of di (2-ethyl hexyl) phthalate by Fusarium culmorum: Kinetics, enzymatic activities and biodegradation pathway based on quantum chemical modeling. Science of the Total Environment. 566-567: 1186-1193.

Ahuactzin-Pérez M., Tecuitl-Beristain S., García-Dávila J., Santacruz-Juárez E., González-Pérez M., Gutiérrez-Ruíz M. \& Sánchez C. 2018. A novel biodegradation pathway of the endocrine-disruptor di(2-ethyl hexyl) phthalate by Pleurotus ostreatus based on quantum chemical investigation. Ecotoxicology and Environmental Safety. 147: 494-499.

Bradford M. M. 1976. A Rapid and sensitive method for the quantitation of microgram quantities of protein utilizing the principle of protein-dye binding. Analytical Biochemistry. 72: 248-254.

Canavati-Alatorre M., Águila I., Barraza-Soltero I., Castillón E., Correa-Barrón A., Sánchez-López E., Conde-Avila V., González-Márquez A., Méndez-Iturbide D., Ruvalcaba D. \& Sánchez C. 2016. Growth and cutinase activity of Fusarium culmorum grown in solid-state fermentation. Mexican Journal of Biotechnology. 1(2): 8-19.

Córdoba-Sosa G., Torres J.L., Ahuactzin-Pérez M., Díaz-Godínez G., Díaz R. \& Sánchez, C. 2014. Growth of Pleurotus ostreatus ATCC 3526 in different 
concentrations of di (2ethylhexyl) phthalate in submerged fermentation. Journal of Chemical, Biological and Physical Sciences. 4(5): 96-103.

Daiem M., Rivera-Utrilla J., Ocampo-Pérez R., Méndez-Díaz J. D. \& Sánchez-Polo M. 2012. Environmental impact of phthalic acid esters and their removal from water and sediments by different technologies-A review. Journal of Environmental Management. 109: 164-178.

Ferrer-Parra L., López-Nicolás D., Martínez-Castillo R., Montiel-Cina J., MoralesHernández A., Ocaña-Romo E., González-Márquez A., Portillo-Ojeda M., Sánchez-Sánchez D. \& Sánchez C. 2018. Partial characterization of esterases from Fusarium culmorum grown in media supplemented with di (2-ethy hexyl phthalate) in solid-state and submerged fermentation. Mexican Journal of Biotechnology, 3(1): 82-94.

Kim, Y., Lee J. \& Moon S. 2003. Degradation of an endocrine disrupting chemical, DEHP (di-(2-ethylhexyl)-phthalate), by Fusarium oxysporum $f$. sp. pisi cutinase. Applied Microbiology and Biotechnology. 63(1): 75-80.

Peropadre A., Fernández-Freire P., Pérez-Martín J., Herrero O. \& Hazen M. 2015. Endoplasmic reticulum stress as a novel cellular response to di(2-ethylhexyl) phthalate exposure. Toxicology in Vitro. 30: 281-287.

Pradeep S. \& Benjamin S. 2012. Mycelial fungi completely remediate di(2ethylhexyl) phthalate, the hazardous plasticizer in PVC blood storage bag. Journal of Hazardous Materials. 235-236: 69-77.

Wittassek, M., Koch H., Angerer J. \& Brüning T. 2010. Assessing exposure to phtalates- The human biomonitoring approach. Mol. Nutr. Food Journal. 55: 7-31.

Yang, T., Ren L., Jia Y., Fan S., Wang J., Wang J., Nahurira R., Wang H \& Yan Y. 2018. Biodegradation of di-(2-etrhylhexyl) Phthalate by Rhodococcus ruber YCYT1 in Contaminated Water and Soil. International Journal of Environmental Research and Public Health. 15: 2-20.

Zhao, H., Du H., Lin J., Chen X., Li Y., Li H., Cai Q., Mo C., Qin H. \& Wong M. 2016. Complete degradation of the endocrine disruptor di-(2-ethylhexyl) phthalate by a novel Agromyces sp. MT-O strain and its application to bioremediation of contaminated soil. Science of the Total Environment. 562: 170-178. 